\title{
Tagging and Mapping Scab Resistance Genes from R12740-7A Apple
}

\author{
Minou Hemmat ${ }^{1}$ and Susan K. Brown \\ Department of Horticultural Sciences, Cornell University, New York State Agricultural Experiment \\ Station, Geneva, NY 14456 \\ Norman F. Weeden \\ Department of Plant Sciences, Montana State University, Bozeman, MT 59717
}

AdDITIONAL INDEX words. Venturia inaequalis, RAPD markers, $V_{r}, V_{r}, \mathrm{SSR}$, STS, Malus

\begin{abstract}
The genetic basis of resistance to apple scab [Venturia inaequalis (Cke.) Wint.] in the Russian apple seedling R12740-7A (Malus Mill. sp.) was investigated. Segregation ratios obtained in crosses with susceptible cultivars suggested that at least two genes were involved, and three foliar resistance reactions (chlorotic, stellate necrotic, and pit type) were observed after inoculation. DNA markers were identified for both the stellate necrotic $\left(V_{r}\right)$ and pit type (no locus designation, $V_{x}$ suggested) resistance phenotypes. Comparison of resistance phenotypes with marker segregation demonstrated that only two major dominant genes were present in R12740-7A, one producing the stellate necrotic lesion and the other the pit-type lesion. The chlorotic lesion could be attributed to either unclear expression of the resistance phenotype or to susceptible genotypes not contracting the disease. These markers along with a previously published marker for $V_{f}$ were used to analyze inheritance of resistance in a $V_{r} \times V_{f}$ cross in advanced breeding material. The markers identified successfully all susceptible progeny, as well as apparent escapes and individuals possessing both $V_{f}$ and $V_{r}$. Thus, the markers should be useful in future screening of segregating progeny and in the pyramiding of scab resistance genes in new cultivars.
\end{abstract}

The most important disease affecting apple $[$ Malus sylvestris $(L)$ Mill. var. domestica (Borkh.) Mansf.] production in many regions is apple scab, caused by the fungus, Venturia inaequalis. By 1969, five distinct scab resistance genes had been identified in apple (Malus sp.) germplasm (Williams and Kuc, 1969). However, only one resistance gene $\left(V_{f}\right)$ has been used extensively in breeding, and studied intensively. While over 50 scab resistant cultivars have been released, the majority possess resistance derived solely from the $V_{f}$ gene of Malusfloribunda Sieb. 821 (Crosby et al., 1992). The report of two new races of scab, race 6 and 7, pathogenic to material containing $V_{f}$ (Bénaouf and Parisi, 2000; Parisi et al., 1993) indicates the need to diversify sources of resistance, or to pyramid several resistance genes into one genotype to prevent resistance breakdown.

The resistant seedling R12740-7A is a selection identified in the United States from open pollinated apple seed obtained from Russia. It represents an alternative source of scab resistance, but has not been used commonly because several modified backcross generations are required to obtain suitable fruit quality (Dayton et al., 1953). R12740-7A has been reported to carry two qualitative genes as well as several quantitative genes for resistance (Dayton et al., 1953). Dayton and Williams (1968) reported that one gene from R12740-7A, designated $V_{r}$, has been found at a separate locus from $V_{f}$. Venturia inaequalis races 2 and 4 have been reported to overcome resistance in differential segregates of R12740-7A. Therefore, Williams and Kuc (1969) have proposed the presence of at least three major genes in R12740-7A, one of which confers resistance to races 1 to 4 , in addition to minor genes. However, these researchers have not described the symptoms observed nor have explained what reaction classes are classified as resistant. Therefore, the genetics of resistance in R12740-7A requires further clarification.

Received for publication 27 Aug. 2001. Accepted for publication 5 Feb. 2002. This research was supported in part by USDA grant NRICRG 93-37300-8776. We would like to dedicate this paper to the memory of the late Frank Cheng for his initiation and contributions to this work.

${ }^{1}$ Corresponding author.
Genetic studies of scab resistance could be complicated by environmental effects on lesion development, seedling stage, concentration of inoculum, isolates included in the inoculum, and the presence of minor genes from the susceptible parent (MacHardy, 1996). Lamb and Hamilton (1969) reported the importance of temperature, photoperiod, and minor genes contributed from the susceptible parent on symptom development and on the percentage of resistant seedlings recovered in a progeny. Kellerhals et al. (1993) examined the reactions of seedlings to two different inoculum sources, and found significant differences in reaction type. They also found an effect of the susceptible parent on the resistance of the progeny. Many reports indicate considerable shifting in the infection ratings among resistant seedlings, whereby seedlings rated as resistant in one test may be rated as susceptible in a different inoculation or location (MacHardy, 1996). These problems emphasize the need for markers to ascertain the genotypes of seedlings without environmental complications and to aid in pyramiding genes for resistance.

While many researchers have been pursuing molecular markers for the $V_{f}$ gene for scab resistance (Gardiner et al., 1996; Hemmat et al., 1998a; Koller et al., 1994; Tartarini, 1996; Yang et al., 1997), there has not been as much research emphasis on other scab resistance genes. Identification of molecular markers linked to specific scab resistance genes from R12740-7A will aid efforts to incorporate these genes into breeding lines and new cultivars. Thus, objectives of our research were to identify markers for all major scab resistance genes present in R12740-7A, study the phenotypic expression of each gene, and evaluate the utility of markers in advanced populations derived from R12740-7A.

\section{Materials and Methods}

Plant material. Two populations of 'Empire' $x$ R12740-7A, consisting of 123 and 192 seedlings, were used to identify DNA markers linked to the different resistance genes. An advanced 
Table 1. Phenotypic classes after inoculation with Venturia inaequalis in seedlings of 'Empire' xRussian seedling R12740-7A (populations 1a and 1b).

\begin{tabular}{|c|c|c|c|c|c|c|c|}
\hline \multirow[b]{2}{*}{ Phenotype } & \multirow{2}{*}{$\begin{array}{c}\text { Total } \\
\text { plants }\end{array}$} & \multirow{2}{*}{$\begin{array}{c}\text { Total } \\
\text { resistant }\end{array}$} & \multicolumn{5}{|c|}{ Reaction to inoculation } \\
\hline & & & $\mathrm{SN}^{\mathrm{z}}$ & $\mathrm{P}^{\mathrm{y}}$ & $\mathrm{SN} / \mathrm{P}^{\mathrm{x}}$ & $\mathrm{Chl}^{\mathrm{w}}$ & $\mathrm{S}^{\mathrm{v}}$ \\
\hline$\overline{\text { Total }}$ & 315 & 240 & 70 & 105 & 56 & 9 & 75 \\
\hline Percentage & 100 & 76 & 22 & 33 & 17 & 3 & 24 \\
\hline
\end{tabular}

${ }^{\mathrm{z} S N}=$ stellate necrotic lesions.

yP $=$ pit-type lesions.

${ }^{\mathrm{x}} \mathrm{SN} / \mathrm{P}=$ individuals scored as $\mathrm{SN}$ then $\mathrm{P}$, or $\mathrm{P}$ then $\mathrm{SN}$.

${ }^{\mathrm{w}} \mathrm{Chl}=$ chlorotic lesions.

${ }^{v} \mathrm{~S}=$ susceptible; class includes any plant with sporulating lesions.

breeding population $(n=63)$ derived from NY 79507-72 $\times$ NY 74827-58 was also examined for reaction to inoculation and to determine the presence of markers for $V_{f}$ and $V_{r}$. NY 79507-72 is known to be heterozygous $\left(V_{f} v_{f}\right)$, and NY 74827-58 is derived from R12740-7A and displayed the stellate necrotic resistance characteristic of $V_{r}$. All crosses were made at the New York State Agricultural Experiment Station, Geneva.

Inoculations. Seedlings from 'Empire' x R12740-7A were germinated at two different times. Population 1a was inoculated in the summer and $1 \mathrm{~b}$ was inoculated in the winter. Seedlings from the above populations were inoculated with a mixture of races 1 to 5 of $V$. inaequalis at the two-leaf stage. Frozen inoculum $\left(2.7 \times 10^{5}\right.$ conidia/mL $)$ was thawed and sprayed on the upper and lower surface of all leaves and cotyledons. Seedlings were maintained at $18{ }^{\circ} \mathrm{C}$ for $48 \mathrm{~h}$ in mist chambers with $\approx 100 \%$ relative humidity to ensure optimum conditions for germination of conidium and infection of plant tissue. Symptoms were observed after $\approx 2$ weeks following inoculation in the greenhouse at $20{ }^{\circ} \mathrm{C}$. Seedlings were classified based on leaf reaction to scab infection using a modification of the classification scheme of Shay and Hough (1952). Class $1=$ pinpoint pits with no sporulation (P type); class 2 = irregular chlorotic (Chl type) or necrotic lesions but without any sporulation. Necrotic lesions were identified as either stellate necrotic (SN type) or irregular necrotic $(\mathrm{N})$. The susceptible class included any seedlings with leaf sporulation. Two weeks after the first inoculation, all plants were scored and reinoculated as described above, and scored again after 2 weeks.

DNA EXTRACTION AND PCR AMPLIFICATION. DNA was extracted from both young and mature leaves as described by Doyle and Doyle (1990). Ten DNA samples for each of the resistance phenotypes (P, SN, and Chl), as well as 10 susceptible individuals were subjected to bulked segregant analysis (BSA) (Michelmore et al., 1991). About 500 random 10-mer primers were screened to identify markers linked to the different resistance reactions. Primers were synthesized at the Cornell University New York State Center for Advanced Technology in Biotechnology, Genosys Biotech, Inc. (Woodlands, Texas), Operon Technologies (Alameda, Calif.), and the University of British Colombia Biotechnology Laboratory (Vancouver, B.C., Canada). The polymerase chain reaction (PCR) were carried out in $16-\mu \mathrm{L}$ volumes containing $14 \mathrm{ng}$ genomic DNA, $11.4 \mu \mathrm{L}$ distilled $\mathrm{H}_{2} \mathrm{O}, 1.7 \mu \mathrm{L}$ $10 \times$ buffer, $1 \mu \mathrm{L}$ of $2.5 \mathrm{~mm} \mathrm{MgCl} 2,0.8 \mu \mathrm{L}$ of each dNTP, $6.5 \mu \mathrm{L}$ of $10 \mu \mathrm{M}$ primer and 0.35 units Taq polymerase (Promega, Madison, Wis.). RAPD amplification was performed in a PTC100 thermalcycler (MJ Research, Watertown, Mass.) programmed as follows: 45 cycles of $94^{\circ} \mathrm{C}, 50 \mathrm{~s} ; 35^{\circ} \mathrm{C}, 30 \mathrm{~s} ; 72^{\circ} \mathrm{C}, 60 \mathrm{~s}$. Simple sequence repeats (SSR) amplification was performed as follows: 40 cycles of $94{ }^{\circ} \mathrm{C}, 60 \mathrm{~s} ; 49$ to $59^{\circ} \mathrm{C}, 120 \mathrm{~s} ; 72^{\circ} \mathrm{C} 120 \mathrm{~s}$, followed by a final cycle of $72^{\circ} \mathrm{C}, 8 \mathrm{~min}$. RAPD products were separated on $2 \%$ agarose gels, and SSR products were separated on $3 \%$ to 4.5\% Nusieve GTG agarose (FMC Bioproducts, Rockland, Maine). After staining with ethidium bromide, gels were observed and photographed under ultraviolet $(\lambda=302 \mathrm{~nm})$ light using Polaroid type 55 film (Polaroid Corp., Cambridge, Mass.).

Cloning and SEQUENCING RAPD FRAGMENTS. Fragments corresponding to $\mathrm{OB} 18_{620}$, the $V_{r}$ marker, and $\mathrm{S} 22_{1300}$, the $V_{x}$ marker, were excised from the gel, and purified using GeneClean (BIO101, Inc., Vista, Calif.). The fragments were ligated directly into PCR 2.1 vector using the TA Cloning System (Invitrogen, San Diego, Calif.). Plasmid DNAs were prepared according to the ABI373A sequencing manual, and fragments were sequenced using an $\mathrm{ABI}$ 373A Sequencer at the Cornell University, New York State Center for Advanced Technology.

AMPLIFICATION OF TARGET FRAGMENTS USING SPECIFIC PRIMERS. Specific primers were designed by extension of random primer sequence to amplify fragments associated with different resistance reactions. Based on sequencing data, the following forward and reverse primers were synthesized: 5'-CCACAGCAGTCATTGGGA-3' and 5'-CCACAGCAGTGCATAAAC-3' for SN resistance phenotype; and 5'-GTCGTGGAAGAGGACCGA-3' and 5-'GTCGTGGAAATCCTCGTGAG-3' for the Presistance phenotype. The amplification reaction contained $20 \mathrm{ng}$ genomic DNA, $18.2 \mu \mathrm{L}$ distilled $\mathrm{H}_{2} \mathrm{O}, 2.5 \mu \mathrm{L} 10 \times$ buffer, $1.5 \mu \mathrm{L}$ of $2.5 \mathrm{~mm} \mathrm{MgCl}_{2}$, $1.25 \mu \mathrm{L}$ of $2.5 \mathrm{~mm}$ of each dNTP, $1.0 \mu \mathrm{L}$ of $10 \mu \mathrm{M}$ of each primer, and 0.5 units $T a q$ polymerase. Total volume was $25 \mu \mathrm{L}$. Cycling parameters consisted of $30 \mathrm{~s}$ at $94{ }^{\circ} \mathrm{C}, 60 \mathrm{~s}$ at $65^{\circ} \mathrm{C}$, and $60 \mathrm{~s}$ at 72 ${ }^{\circ} \mathrm{C}$ for 40 cycles. Amplification products were separated on $2 \%$ agarose gel, and stained with ethidium bromide.

\section{Results and Discussion}

RESistanCE PHENOTYPES IN RESPONSE TO INOCUlATION. Data from the two inoculations were combined. The following categories were established based on inoculation ratings for both populations: $22 \%$ stellate necrotic (SN), 33\% pinpoint pit (P), $17 \%$ $\mathrm{SN} / \mathrm{P}, 3 \%$ irregular chlorotic lesions with wrinkling $(\mathrm{Chl})$, and $24 \%$ susceptible (Table 1, Fig. 1). The SN/P group had one reaction type (either $\mathrm{SN}$ or $\mathrm{P}$ ) during the first inoculation. In this group, those with $\mathrm{SN}$ reaction in the first inoculation developed a $\mathrm{P}$ reaction in the second inoculation and those with $\mathrm{P}$ reaction developed a SN reaction in the second inoculation.

Bulked segregant analysis (BSA) was used for identification of RAPD markers linked to each phenotypic class. Ten individuals from the SN class and 10 from the susceptible class were used to form two bulk samples for identification of markers linked to $\mathrm{SN}$. The $\mathrm{P}$ and SN/P classes were not included at this stage.

DNA MARKER FOR STELLATE NECROTIC (SN) RESISTANCE. A 620base pair (bp) fragment produced by OPB18 (5'-CCACAGCAGT3 ') cosegregated with all but three $\mathrm{SN}$ resistant phenotype seedlings 

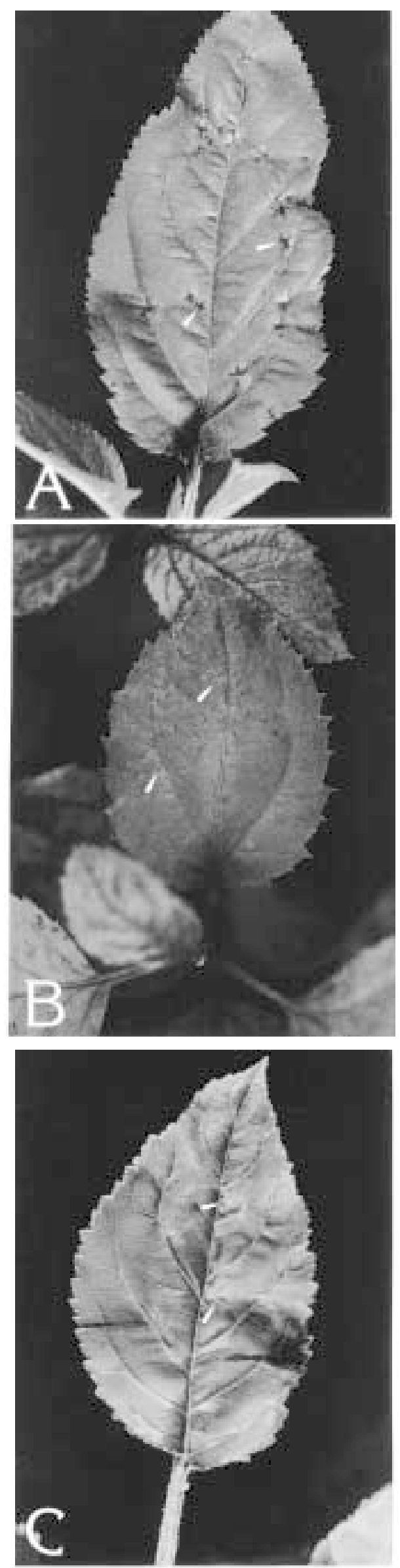

Fig. 1. Different resistance reactions (indicated by arrows) observed in seedlings of 'Empire' $x$ Russian seedling R12740-7A, following inoculation with Venturia inaequalis. (A) Stellate necrotic (SN) lesion, (B) pit (P) lesion, and (C) chlorotic (Chl) reaction.

(Fig. 2) and was present in one susceptible seedling (Table 2). The marker for $\mathrm{SN}$ resistance segregated $\approx 1: 1$. A 122 -bp fragment produced from SSR primers developed by Gianfranceschi et al. (1998) was also found to be associated with the SN phenotype (Fig. 3, Table 2). SSR CH02B10 (forward primer 5'CAAGGAAATCATCAAAGATTCAAG3' and reverse 5'-CAAGTGGCTTCGGATAGTTG-3') was on the opposite side of OPB $18_{620}$ from the gene generating the SN phenotype. In two susceptible seedlings, the SSR band was present whereas OB $18_{620}$ was absent. Among 23 SN/P class, the SSR marker was absent in three individuals. Of $37 \mathrm{P}$ type individuals, 15 had both the SSR and OB18 ${ }_{620}$ markers, while 22 lacked the SSR and OB $18_{620}$ bands (Table 3). Thus, SSR CHO2B10 122 was useful in differentiating any $\mathrm{P}$ types from SN type (seedlings with a pit phenotype as the stellate necrotic lesion did not fully develop). Such individuals amplified both fragments. The two markers, OPB $18_{620}$ and CHO2B10, flanked the $V_{r}$ gene.

DNA MARKER FOR PIT-TYPE (P) RESISTANCE. Data from the two inoculations for populations 1a and 1b ('Empire' xR127407A) were combined for marker analysis associated withPtype reaction. Ten samples from P phenotype seedlings and 10 samples from susceptible seedlings were used for BSA to identify RAPD markers that cosegregated with P reaction type. Progeny in the SN and P/SN classes were not included at this stage. BSA identified a 1300bp fragment generated from primer S22 (5'CGTCGTGGAA-3') and a 300-bp fragment from primerP11 (5'-CTGTGCTGTG$\left.3^{\prime}\right)$, and both were associated with the $P$ phenotype. The 1300-bp fragment was present in 146 resistant $P$ phenotypes and in 11 susceptible seedlings, but absent in $15 \mathrm{P}$ phenotype individuals and in 73 susceptible seedlings (Table 4). The marker for $\mathrm{P}$ resistance segregated $\approx 1: 1$. The marker $\mathrm{S} 22_{1300}$, associated with the $\mathrm{P}$ phenotype, predicted the presence of a second gene, $V_{x}$. When the two markers OPB $18_{620}$ and $\mathrm{S} 22_{1300}$ were combined, 63 individuals in the susceptible class had neither marker, and 3\% of the seedlings with chlorotic lesions also had neither marker. Three individuals in the SN class also did not have the OPB $18_{620}$ marker. Most individuals (83\%) had consistent reaction responses in the two inoculations. In $17 \%$ of the seedlings (the $\mathrm{SN} / \mathrm{P}$ group), resistant reactions were inconsistent; an individual scored either SN or $\mathrm{P}$ in the first inoculation might be scored as a different reaction type ( $\mathrm{P}$ or $\mathrm{SN}$ ) following the second inoculation. However, the percentage of seedlings in each resistance group was similar in populations $1 \mathrm{a}$ and $1 \mathrm{~b}$. Fewer seedlings with the $\mathrm{SN}$ reaction were scored after the second inoculation in both summer (a) and winter (b) tests, indicating that inoculations should be conducted at an early stage of seedling growth to maximize detection of all present phenotypes.

Of 56 plants in SN/P class, 52 had both markers, three had markers for SN but not for $\mathrm{P}$ phenotype, and only one lacked the marker for the SN phenotype. Neither marker was linked to the nine Chl seedlings. This resistance reaction might be influenced by presence of minor genes or might be escapes. The pinpoint pit reaction, classified as a hypersensitive response, was produced by a second resistance gene, designated as $V_{x}$.

About $25 \%$ susceptible seedlings have been observed and are explained by a model in which two dominant genes control resistance to apple scab. Recombination values in our population can best be estimated from the number of the susceptible plants amplifying OPB $18_{620}$ and $\mathrm{S} 22_{1300}$ fragments. Therefore, recombination frequency for OPB $18_{620}$ and $V_{\mathrm{r}}$ is $\approx 1$ out of 75 and for $\mathrm{S} 22_{1300}$ and $V_{x}$ is $\approx 11$ out of 75 .

\section{$M 123456789101112131415161718192021222324252627$}

$1000 \mathrm{bp}$

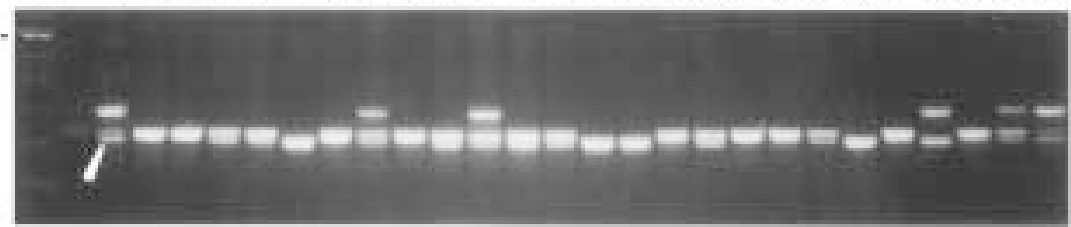

Fig. 2. Segregation of a marker from primer OPB18 linked to stellate necrotic (SN) resistance phenotype in seedlings of 'Empire' $x$ Russian seedling R12740-7A. Lane M, 100 bp DNA ladder; lane 1, 'Empire'; lane 2, Russian seedling R12740-7A; and lanes 3 to 27, the segregating population, with resistant individuals amplifying the 620-bp fragment (shown by arrow) generated from a RAPD primer. 
Table 2. Segregation of OPB18 (620 bp) and SSR (CHO2B10) markers linked to stellate necrotic $(\mathrm{SN})$ resistance reaction to Venturia inaequalis in seedlings of 'Empire' $x$ Russian R12740-7A (populations $1 \mathrm{a}$ and $1 \mathrm{~b})$.

\begin{tabular}{lcr}
\hline \hline & \multicolumn{2}{c}{ Reaction to inoculation } \\
\cline { 2 - 3 } Phenotype & $\mathrm{SN}^{\mathrm{z}}$ & $\mathrm{S}^{\mathrm{y}}$ \\
\hline OPB18 & & \\
Presence & 123 & 1 \\
Absence & 3 & 74 \\
CH02B10 & & \\
Presence & 46 & 2 \\
Absence & 2 & 31
\end{tabular}

${ }^{\mathrm{z}} \mathrm{SN}=$ stellate necrotic lesions.

${ }^{\mathrm{y}} \mathrm{S}=$ susceptible; class includes any plant with sporulating lesions.

DEVELOPMENT OF SEQUENCE-TAGGED SITE (STS) BY DESIGNING SPECIFIC PRIMERS FOR OPB18 620 AND S22 1300 MARKERS. Amplification of S22 1300 fragment using specific primers (19-mer and 20mer) linked to pit-type resistance, was successful at an annealing temperature of $65^{\circ} \mathrm{C}$. The fragment was present in most progeny with $\mathrm{P}$ phenotype, but absent in susceptible seedlings and those with SN phenotype (Fig 4). We were unable to develop specific primers that would only amplify the 620-bp fragment in resistant seedlings. Specific primers designed (12-, 14-, 16-, and 18-mers) for 620-bp fragment generated similar size fragment in all seedlings. However, SSR CH02B $10_{122}$ could serve as a specific primer for $\mathrm{SN}$ resistance (Fig. 3).

The inoculation results and molecular marker analyses indicate that R12740-7A possesses two major genes conferring resistance to apple scab, one gene conferring $\mathrm{P}$ phenotype and another gene conferring the SN phenotype resistance reaction. Both resistance genes appear to be dominant. The stellate necrotic (SN) reaction is typically associated with R12740-7A-derived resistance and corresponds to the $V_{r}$ gene. The flanking markers, SSR CH02B10 ${ }_{122}$ and OPB18 $8_{620}$, can be used together to insure selection of all $\mathrm{SN}$ resistant individuals.

MAPPING $\boldsymbol{V}_{\boldsymbol{r}}$ AND $\boldsymbol{V}_{\boldsymbol{x}}$ RESISTANCE GENES. We reported previously the location of 39 SSRs on the linkage map of apple (Hemmat et al., 1998b), and mapped CH02B10 122 on linkage group 11 of 'White Angel' x 'Rome Beauty' (Hemmat et al., 1994), and the corresponding linkage group in 'Wijcik McIntosh' xNY 7544158 population (Conner et al., 1997). Therefore, the $V_{r}$ gene is on the corresponding linkage group for R12740-7A flanked by OB $18_{620}$ and $\mathrm{CH} 02 \mathrm{~B} 10_{122}$ (Fig. 5A). BSA identified two close markers (S22 1300 and $\left.\mathrm{P} 11_{300}\right)$ for $V x$ in 'Empire' $\mathrm{x}$ R12740-7A. Both fragments were segregating 1:1 in 'White Angel' $\mathrm{x}$ 'Rome Beauty' mapping population, but we could not assign these
130

120

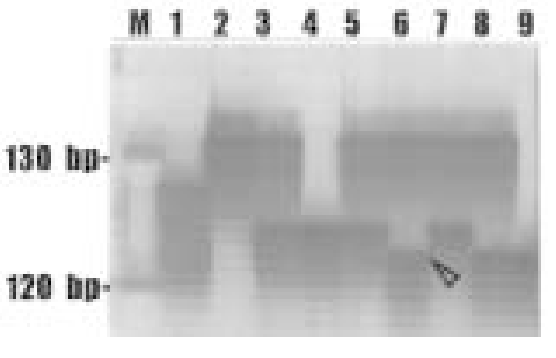

Fig. 3. Segregation of SSR marker CH02B10 linked to stellate necrotic (SN) resistance phenotype in seedlings of 'Empire' $\mathrm{x}$ Russian seedling R12740-7A.Lane M, 10bp DNAladder; lane 1, Russianseedling R12740-7A; lane 2, 'Empire'; and lanes6,8, and 9; Resistantindividuals amplifying the 122 bp fragment (indicated by arrow) generated from the SSR primer. markers to any linkage group. In 'Wijcik McIntosh' xNY7544158 mapping population, these fragments were monomorphic. Therefore, we tried to identify new markers on either side of $V_{x}$ and further from $V_{x}$ to map this gene. BSA identified two new markers, PGAjf28 $8_{950}\left(5^{\prime}\right.$-AGTCTATATTGCTAGACC-3') and $\mathrm{S6}_{980}\left(5^{\prime}\right.$-CCGCTTCTGT-3') linked to $V_{x}$ in 'Empire' $\mathrm{xR} 12740$ 7A. A map of the $V_{x}$ region was constructed using four markers (Fig. 5B). Primer S6 did not amplify a 980-bp fragment in either mapping population. PGAjf $28_{950}$ amplified and segregated in both mapping populations, and was mapped on linkage group 6 of 'White Angel' $x$ 'Rome Beauty' and the corresponding linkage group 10 of 'Wijcik McIntosh' $\mathrm{x}$ NY 75441-58. It appeared that $V_{x}$ is distinct from $V_{m}$ because the marker for $V_{m}$ (Cheng et al., 1998) was not present in the R12740-7A and the S22 marker linked to $V_{x}$ in R12740-7A could not be amplified in either $M$. micromalus and $M$. atrosanguinea.

DIFFERENTIALS FOR $\boldsymbol{V}$. inaequalis RACES 2 AND 4. Some progeny from R12740-7A were found to be susceptible to either race 2 or race 4 of $V$. inaequalis (Williams and Kuc, 1969). These seedlings along other cultivars with differential resistance have been maintained as indicator plants for distinguishing all races of $V$. inaequalis (Lespinasse, 1994). Three differentials susceptible to race 2 ('Geneva', 'Dolgo', and GMAL 2411) amplified OB18 ${ }_{620}$, but did not amplify S22 1300 . Yet another differential for race 2, W7AR44T20 (GMAL 2415) did not amplify OB18 ${ }_{620}$, but amplified S22 1300 . TSR18T13 (PRI 1290-3) (a race 4 differential) did not amplify either marker.

SCREENING FOR $\boldsymbol{V}_{\boldsymbol{f}}$ AND $\boldsymbol{V}_{\boldsymbol{r}}$. In the NY 79507-72 $\left(V_{f} v_{f}\right) \times \mathrm{NY}$ 74827-58 $\left(V_{r} v_{r}\right)$ progeny, OPM18 $8_{900}$ (known to be about $2 \mathrm{cM}$ from $V_{f}$ ) and OPB $18_{620}$ (our $V_{r}$ marker) were segregating. However, $S 22_{1300}$ was absent from all progeny, suggesting that the gene conferring $\mathrm{P}$ type response was absent. The two markers gave a segregation ratio close to the expected $1: 1: 1: 1$, suggesting that both loci were segregating as expected (Table 5). All 12 plants scored susceptible and an additional four plants, showing Chl-type reaction, lacked both markers. All plants scored phenotypically as $\mathrm{SN}$ or $\mathrm{N}$ after at least one inoculation (14 plants) possessed the $V_{r}$ marker OPB $18_{620}$. Three of these plants, all in the

Table 3. Segregation of a marker from SSR primer $\left(\mathrm{CH} 02 \mathrm{~B} 10_{122}\right)$ linked to SN (stellate necrotic) resistance reaction to Venturia inaequalis in seedlings of 'Empire' $x$ R12740-7A (population 1a).

\begin{tabular}{|c|c|c|c|c|c|c|c|}
\hline \multirow[b]{2}{*}{ Phenotype } & \multirow{2}{*}{$\begin{array}{l}\text { Total } \\
\text { plants }\end{array}$} & \multicolumn{5}{|c|}{ Reaction to inoculation } & \multirow{2}{*}{$\begin{array}{c}\text { Total } \\
\text { resistant }\end{array}$} \\
\hline & & $\mathrm{SN}^{\mathrm{z}}$ & $\mathrm{P}^{\mathrm{y}}$ & $\mathrm{SN} / \mathrm{P}^{\mathrm{x}}$ & $\mathrm{Chl}^{\mathrm{w}}$ & $\mathrm{S}^{\mathrm{v}}$ & \\
\hline \multicolumn{8}{|l|}{$\overline{\mathrm{CH}} 02 \mathrm{~B} 10_{122}$} \\
\hline Presence & 64 & 26 & 15 & 20 & 1 & 2 & 62 \\
\hline Absence & 59 & 2 & 22 & 3 & 1 & 31 & 28 \\
\hline
\end{tabular}

${ }^{\mathrm{z}} \mathrm{SN}=$ stellate necrotic lesions.

yP $=$ pit-type lesions.

${ }^{\mathrm{x}} \mathrm{SN} / \mathrm{P}=$ individuals scored as $\mathrm{SN}$ then $\mathrm{P}$, or $\mathrm{P}$ then $\mathrm{SN}$.

${ }^{\mathrm{w}} \mathrm{Chl}=$ chlorotic lesions.

${ }^{\mathrm{v}} \mathrm{S}=$ susceptible; class includes any plant with sporulating lesions. 
Table 4. Segregation of a marker from primer S22 (1300 bp) linked to pittype $(\mathrm{P})$ resistance reaction to Venturia inaequalis in seedlings of 'Empire' x R12740-7A (Population 1a, 1b).

\begin{tabular}{lrc}
\hline & \multicolumn{2}{c}{ Reaction to inoculation } \\
\cline { 2 - 3 } Phenotype & $\mathrm{P}^{\mathrm{z}}$ & $\mathrm{S}^{\mathrm{y}}$ \\
\hline S22 1300 & 146 & 11 \\
Presence & 15 & 73 \\
Absence &
\end{tabular}

${ }^{\mathrm{z}} \mathrm{P}=$ pit-type lesions.

${ }^{\mathrm{y}} \mathrm{S}=$ susceptible; class includes any plant with sporulating lesions.
SN/P class, also displayed the $V_{f}$ marker. Those plants possessing only the $V_{f}$ marker, were scored Chl, except for one plant scored $\mathrm{Chl} / \mathrm{P}$. The seedlings amplified both markers or the $V_{r}$ marker alone were the most variable in regard to resistance phenotype. Those with both markers were in six different response categories, most of which contained the $\mathrm{SN}$ or $\mathrm{N}$ response as noted above, whereas seedlings with the $V_{r}$ marker comprised four responses, including the unexpected $\mathrm{P}$ response. Of 11 plants with a $P$ phenotypic reaction after at least one of the inoculations, eight possessed both markers.

Results obtained from this advanced population indicate that the two markers will be effective in marker-assisted selection. Both markers were absent in all plants scored susceptible. Four plants that lacked both markers but were scored as resistant $(\mathrm{Chl})$ were probably escapes. The Chl type is characteristic of $V_{f}$ only, or $V_{f}$ plus $V_{r}$. If a recombination event had occurred between the OPM18 ${ }_{900}$ marker and the $V_{f}$ locus, then $V_{f}$ would be absent, otherwise, two recombination events would be required. However,

Fig. 4. Segregation of dominant marker linked to pit $(\mathrm{P})$ resistance phenotype amplified using STS primers. Lane M, 100-bp DNA ladder; lane 1, Russian seedling R12740-7A; lane 2, Empire'; and lanes 3 to 27; the segregating population, with resistant individuals amplifying the 1300 -bp fragment generated from specific primers.
(A)

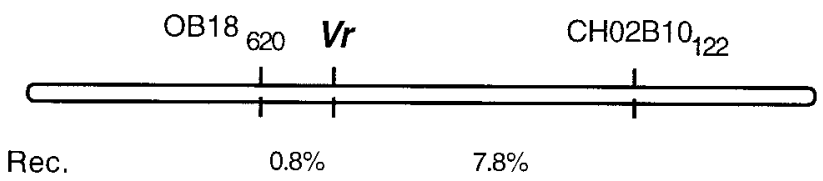

(B)

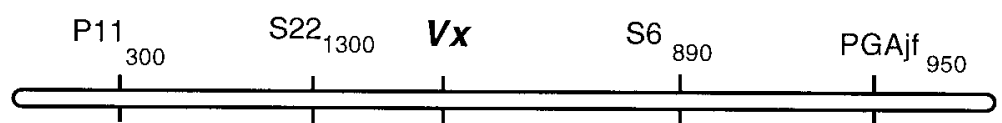

Rec.

\begin{abstract}
$20 \%$
$8.5 \%$

$23 \%$
\end{abstract}

the distance between OPM $18_{900}$ and $V_{f}$ was about $2 \mathrm{cM}$ (Koller et al., 1994); therefore the latter events were unlikely to occur.

The wide range of phenotypes observed for at least two of the marker genotypes further emphasized the difficulties inherent in inoculations of seedlings. Identification of plants with both resistance genes solely on the basis of phenotype would not be very successful. Most of the plants carrying both resistance genes displayed the same resistance phenotype (Chl) as plants carrying only $V_{f}$, suggesting that phenotypically, $V_{f}$ is usually epistatic to $V_{r}$. This is in contrast to previous findings by Aldwinckle et al. (1976). Interestingly, those $V_{r}$ and $V_{f}$ plants exhibiting a phenotype other than Chl showed an unexpected pit-type reaction. We do not believe that this pit-type reaction is due to the other resistance gene in R12740-7A because the marker for this gene is absent from the population and the segregation of

Fig. 5. (A) Genetic map of the $V_{r}$ region constructed from progeny of 'Empire' $\mathrm{x}$ Russian seedling R12740-7A. The $V_{r}$ gene is flanked by OPB18 ${ }_{620}$ and SSR marker $\mathrm{CH} 02 \mathrm{~B} 10$ with $0.8 \%$ and $7.8 \%$ recombination between the markers, respectively. (B) Genetic map of the $V_{x}$ region constructed from progeny of 'Empire' x R12740-7A. S22 ${ }_{1300}$, was the closest marker to $V_{x}$ with $8.5 \%$ recombination. Percent recombination between adjacent markers in the linkage map is demonstrated.
$20 \%$ resistance can be explained on the basis of a two gene $\left(V_{f}-V_{r}\right)$
model. Rather, the P reaction probably reflects a general phenotype that is generated occasionally by the interaction of $V_{f}$ and $V_{r}$. With the availability of markers for $V_{f}, V_{m}, V_{r}$, and $V_{x}$ scab resistance genes, it is now easier to investigate interactions among these genes, as well as to pyramid these genes into cultivars that will possess durable resistance to apple scab.

Table 5. Segregation of markers from primers OPM18 ${ }_{900}$ and OPB $18_{620}$ linked to resistance reaction to Venturia inaequalis in seedlings of NY 79507 $72\left(V_{f} v_{f}\right) \times \mathrm{NY} 75428-57\left(V_{r} v_{r}\right)$.

\begin{tabular}{|c|c|c|c|c|c|c|}
\hline \multirow[b]{2}{*}{ OPM18 ${ }_{900 /} \mathrm{OPB} 18_{620}$} & \multirow[b]{2}{*}{ Total } & \multicolumn{5}{|c|}{ Reaction to inoculation $^{2}$} \\
\hline & & $\mathrm{SN} / \mathrm{P}$ & Chl & $\mathrm{Chl} / \mathrm{SN}$ & $\mathrm{Chl} / \mathrm{P}$ & $\mathrm{S}$ \\
\hline Presence/present & 18 & 3 & 10 & 0 & 5 & 0 \\
\hline Presence/absence & 16 & 0 & 15 & 0 & 1 & 0 \\
\hline Absent/present & 13 & 2 & 1 & 9 & 1 & 0 \\
\hline Present/absent & 16 & 0 & 4 & 0 & 0 & 12 \\
\hline
\end{tabular}

${ }^{\mathrm{z}} \mathrm{SN} / \mathrm{P}=$ individuals scored as $\mathrm{SN}$ then $\mathrm{P}$, or $\mathrm{P}$ then $\mathrm{SN}$; Chl = chlorotic lesions; Chl/SN = individuals scored as Chl then SN, or SN then Chl; Chl/ $\mathrm{P}=$ individuals scored as $\mathrm{Chl}$ then $\mathrm{P}$, or $\mathrm{P}$ then $\mathrm{Chl} ; \mathrm{S}=\mathrm{S}=$ susceptible, class includes any plant with sporulating lesions. 


\section{Literature Cited}

Aldwinckle, H.S., H.L. Gustafson, and R.C. Lamb. 1976. Early determination of genotypes for apple scab resistance by forced flowering of test cross progenies. Euphytica 25:185-191.

Bénaouf, G. and L. Parisi. 2000. Genetics of host-pathogen relationship between Venturia inaequalis races 6 and 7 and Malus species. Phytopathology 90:236-242.

Cheng, F.S., N.F. Weeden, S.E. Gardiner, and V.G. Bus. 1998. Development of a DNA marker for $V_{m}$, a gene conferring resistance to apple scab. Genome 41:208-214

Conner, P.J., S.K. Brown, and N.F. Weeden. 1997. Randomly amplified polymorphic DNA-based genetic linkage map of three apple cultivars. J. Amer. Soc. Hort. Sci. 122:350-359.

Crosby, J.A., J. Janick, P.C. Pecknold, S.S. Korban, P.A. O’Conner, S.M. Ries, J. Goffreda, and A. Voordeckers. 1992. Breeding apples for scab resistance: 1945-1990. Fruit Var. J. 46:145-166.

Dayton, D.F., J.R. Shay, and L.F. Hough. 1953. Apple scab resistance from R12740-7A, a Russian apple. Proc. Amer. Soc. Hort. Sci. 62:334340.

Dayton, D.F. and E.B. Williams. 1968. Independent genes in Malus for resistance to Venturia inaequalis. Proc. Amer. Soc. Hort. Sci. 92:8993.

Doyle, J.J. and J.L. Doyle. 1990. Isolation of plant DNA from fresh tissue. Focus 12:13-15.

Gardiner, S.E., H.C.M. Basset, D.A.M. Noiton, V.G. Bus, M.E. Hofstee, A.G. White, R.D. Ball, R.L.S. Foster, and E.H.A. Rikkerink. 1996. A detailed linkage map around an apple scab resistance gene demonstrates that two resistance classes both carry the $V_{f}$ gene. Theor. Appl. Genet. 93:485-493.

Gianfranceschi, L., N. Seglias, R. Tarchini, M. Komanc, and C. Gessler. 1998. Simple sequence repeats for the genetic analysis of apple. Theor. Appl. Genet. 96:1069-1076.

Hemmat, M., N.F. Weeden, H.S. Aldwinckle, and S.K. Brown. 1998a. Molecular markers for the scab resistance $\left(V_{f}\right)$ region in apple. J. Amer. Soc. Hort. Sci. 123:992-996.

Hemmat, M., N.F. Weeden, A.G. Manganaris, and D.M. Lawson. 1994. Molecular marker linkage map for apple. J. Hered. 85:4-11.
Hemmat, M., N.F. Weeden, A.K. Scewz-McFadden, R.K. McKee, and S.K. Brown. 1998b. Mapping and evaluation of Malus $\times$ domestica microsatellites in apple and pear. Plant and animal genome VI. San Diego, Calif. p. 280 (abstr.).

Kellerhals, M., A. Fouillet, and Y. Lespinasse. 1993. Effect of the scab inoculum and the susceptible parent on resistance to apple scab (Venturia inaequalis) in the progenies of crosses to the scab resistant cv. 'Florina'. Agronomie 13:631-636.

Koller, B., L. Gianfranceschi, N. Seglias, J. McDermott, and C. Gessler. 1994. DNA markers linked to Malus floribunda 821 scab resistance. Plant Mol. Biol. 26:597-602.

Lamb, R.C. and J.M. Hamilton. 1969. Environmental and genetic factors influencing the expression of resistance to scab [Venturia inaequalis (Cke.) Wint.] in apple progenies. J. Amer. Soc. Hort. Sci. 94:554-557.

Lespinasse, Y. 1994. Apple scab resistance and durability: New races and strategies for the future, p. 105-106. In: H. Schmidt and M. Kellerhals (eds.). Progress in temperate fruit breeding. Kluwer Academic Publishers, Dordrecht, The Netherlands.

MacHardy, W.E. (ed.). 1996. Inheritance of resistance to Venturia inaequalis, p. 61-103. In: Apple scab-Biology, epidemiology and management. APS Press, St. Paul, Minn.

Michelmore, R.W., I. Paran, and R.V. Kesseli. 1991. Identification of markers linked to disease resistance genes by bulked segregant analysis: A rapid method to detect markers in specific genomic regions by using segregating populations. Proc. Natl. Acad. Sci. USA 88:98289832.

Parisi, L., Y. Lespinasse, J. Guillaumes, and J. Kruger. 1993. A new race of Venturia inaequalis virulent to apples with resistance due to the $V_{f}$ gene. Phytopathology 83:533-537.

Shay, J. R and L.F. Hough. 1952. Evaluation of apple scab resistance in selections of Malus. Amer. J. Bot. 39:288-297.

Tartarini, S. 1996. RAPD markers linked to the $V_{f}$ gene for scab resistance in apple. Theor. Appl. Genet. 92:803-810.

Williams, E.B. and J. Kuc. 1969. Resistance in Malus to Venturia inaequalis. Annu. Rev. Phytopathol. 7:223-246.

Yang, H.Y., S.S. Korban, J. Kruger, and H. Schmidt. 1997. A randomly amplified polymorphic DNA (RAPD) marker tightly linked to the scab resistant gene $V_{f}$ in apple. J. Amer. Soc. Hort. Sci. 122:47-52. 